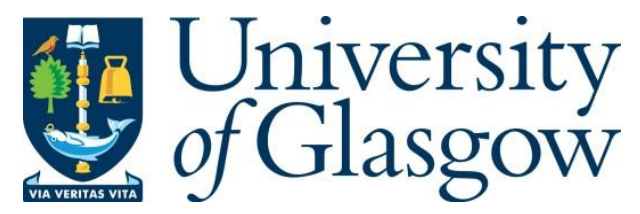

Lindsay, B. (2018) Fostering in a new age of vicarious liability? Edinburgh Law Review, 22(2), pp. 294-301.(doi:10.3366/elr.2018.0489)

This is the author's final accepted version.

There may be differences between this version and the published version. You are advised to consult the publisher's version if you wish to cite from it.

http://eprints.gla.ac.uk/162381/

Deposited on: 11 June 2018

Enlighten - Research publications by members of the University of Glasgow http://eprints.gla.ac.uk 


\section{Fostering in a New Age of Vicarious Liability?*}

\section{A. INTRODUCTION}

In Armes v Nottinghamshire County Council, ${ }^{1}$ the UK Supreme Court considered the liability of a local authority for abuse which had been suffered by the claimant as a child, after being placed by the local authority with foster parents. Was the local authority responsible, either directly or vicariously, for the abuse perpetrated by the foster parents? The claim based on direct liability - alleging a breach of a non-delegable duty to ensure that care was taken of the claimant - was dismissed unanimously. ${ }^{2}$ However, a majority held that the defendant would be vicariously liable for the abuse. The decision continues, in an accelerative fashion, the trend of extending the personal scope of vicarious liability beyond the paradigmatic employer-employee relationship. ${ }^{3}$

This note takes stock of this extension and considers its application to the fostering regime in Scotland. Fostering is part of the suite of methods which a Scottish local authority can employ to arrange for the care of looked-after children. Children in need of care may be placed, under local authority's supervision, with a parent (referred to as "looked after at home care"), ${ }^{4}$ or with a relative or family friend ("kinship care"). ${ }^{5}$ Where this is not possible, the child may be placed into residential care. ${ }^{6}$ The local authority also may apply for a permanence order empowering it to regulate the residence of the child, ${ }^{7}$ which may or may not include authority for the child to be adopted. ${ }^{8}$ And in some cases, the authority may seek to arrange for the child to be adopted, transferring all parental responsibilities and rights to the adopters. ${ }^{9}$ A relative newcomer to this landscape is the "corporate parent", which are institutions (e.g. NHS trusts, Police Scotland, universities) tasked with promoting the

\footnotetext{
* Published as (2018) Edinburgh Law Review

${ }^{1}$ [2017] UKSC 60; [2017] 3 WLR 1000.

${ }^{2}$ Armes, para [40]-[51] per Lord Reed; para [75], per Lord Hughes. This note will not discuss this point.

${ }^{3}$ See Various Claimants $v$ Institute of the Brothers of the Christian Schools [2012] UKSC 56; [2013] 2 AC 1 (“Christian Brothers”); Cox v Ministry of Justice [2016] UKSC 10; [2016] AC 660 (“Cox”). See also Various Claimants v Barclays Bank Plc [2017] EWHC 1929 (QB).

4 The Looked After Children (Scotland) Regulations 2009, SSI 2009/210, Part IV.

${ }^{5}$ Ibid, Part V.

${ }^{6}$ Children (Scotland) Act 1995, section 26(1)(b); The Residential Establishments - Child Care (Scotland) Regulations 1996, SSI 1996/3256.

${ }^{7}$ Adoption and Children etc (Scotland) Act 2007, sections 80-86.

${ }^{8}$ Adoption and Children etc (Scotland) Act 2007, section 80(2)(c) and section 83.

${ }^{9}$ Adoption and Children etc (Scotland) Act 2007, Part 1, especially sections28-34.
} 
interests of looked-after children and care-experienced young people. ${ }^{10}$ This note, however, focuses primarily on the position of foster carers, as did the decision in Armes.

\section{B. FACTS AND LEGISLATIVE CONTEXT}

The claimant was taken into the care of the defendant in 1985, which placed her with a series of foster parents. She suffered physical, emotional, and sexual abuse during two of these placements. Years later, she claimed compensation from the defendant local authority on the basis of its vicarious liability for the abuse, which had to be determined in accordance with the legislative regime in force at the time of the abuse.

In outline, the defendant selected the foster parents, provided relevant training, appointed a social worker to dispense guidance throughout the placement, paid allowances, reimbursed expenses, and provided loans of essential equipment. The child was assigned her own social worker who visited the family home regularly. The parents also had to present the children for medical examination at the order of the defendant, which retained the power to consent to the child's treatment. The defendant's approval was necessary before the child could go on holiday, attend school trips, or sleep over with friends. Ultimately, the defendant could remove the child from the foster home if it deemed the placement no longer to be in the child's best interests.

Against this background, Males $\mathrm{J}^{11}$ and the Court of Appeal ${ }^{12}$ held that the relationship between the foster parents and the local authority was not one which gave rise to vicarious liability. This prompted the claimant's appeal to the UK Supreme Court.

\section{VICARIOUS LIABILITY: AN OVERVIEW}

A defendant will be vicariously liable for a tortfeasor's acts if:

(1) the relationship between the defendant and the tortfeasor is such as to give rise to vicarious liability (a "relationship akin to employment"), and;

(2) the tortfeasor's acts or omissions are so closely connected with its relationship with the defendant to make it fair, just and reasonable for the defendant to be vicariously liable for them.

Armes considered the first criterion: was the local authority vicariously liable for the tort of a foster parent with whom it had placed a child in exercise of its statutory powers? As the

\footnotetext{
${ }^{10}$ Children and Young People (Scotland) Act 2014, Part 9.

${ }^{11}$ Sub nom NA v Nottinghamshire County Council [2014] EWHC 4005 (QB).

12 [2015] EWCA Civ 1139; [2016] QB 739.
} 
situation involved no formalised employment or agency agreement, the question was whether or not that relationship could be characterised as one "akin to employment".

In Christian Brothers, the Supreme Court identified five features of the employee/employer relationship which justified the imposition of vicarious liability: ${ }^{13}$

1. The employer usually will be better-resourced to meet any award of compensation made to the victim;

2. The tort will have resulted from activity carried out by the employee on behalf of the employer;

3. The employee's activity will be part of the employer's business activities;

4. The business activity of the employer will have created the risk of the tort which befell the victim;

5. The employer will exercise a degree of control over the employee.

If the relationship under examination also evidences these factors, then the imposition of vicarious liability may be justified. Importantly, "business" is not to be read as solely limiting the doctrine's application to activities of a commercial or profit-making nature. ${ }^{14}$ So long as the tortfeasor does not carry out a "recognisably independent business", then the defendant may be held vicariously liable for torts committed in the course of activities which were integral to the defendant's business. ${ }^{15}$

As Lord Hughes recognised in Armes, ${ }^{16}$ some of these factors are of dubious value as touchstones for application in case-by-case assessments of the relevant relationship. Resource considerations and the fact that the defendant's engagement of the tortfeasor has created the risk of a tort being committed in the course of the relevant activities simply are general justifications for the doctrine of vicarious liability and are of no use in assessing the nature of the relevant relationship in individual cases. As Lord Hughes observed, ${ }^{17}$ the only factors of assistance in individual determinations are the degrees of integration and control, on which this note will focus. However, even pared down to these two factors, Armes demonstrates that, once one strays from the archetypal employee-employer relationship, the assessment of the relevant relationship is no easy matter.

${ }^{13}$ Christian Brothers, para [35]; see also Cox, paras [20]-[25]; Armes, paras [56]-[58].

${ }^{14}$ Cox, para [30].

${ }^{15}$ Cox, para [29].

${ }^{16}$ Armes, para [77].

${ }^{17}$ Armes, para [77]. 


\section{D. “A RELATIONSHIP AKIN TO EMPLOYMENT": APPLICATION}

\section{Vicarious Liability Established: Lord Reed (Majority)}

Lord Reed identified the relevant "business" activity of the local authority as "the care of children who had been committed to their care" ${ }^{18}$ A number of factors demonstrated the integration of the foster parents with that activity: ${ }^{19}$ they were recruited and trained by the local authority to provide care; they were paid allowances to indemnify any expenses incurred in the raising of the child; they were expected to co-operate and frequently liaise with social workers regarding the child's upbringing; and, if deemed to be conducive to the child's development, they were obliged to permit contact with the child's biological family. One could not demarcate between the activity of the local authority, "who were responsible for the care of the child and the promotion of her welfare", and the foster carers whom the local authority had selected as the best vessel to provide care that satisfied the child's welfare needs. ${ }^{20}$

As for the issue of control, while the foster parents retained discretion as to the day-today running of the family home, with no consistent, "ground-level" oversight or "micromanagement", there nevertheless was a "significant degree of control over both what the foster parents did and how they did it...."21 The local authority initially selected the foster parents, monitored the placement for its duration, were to be informed of any serious incident befalling the child, were to be permitted to visit the property and see the child at any time, had the power to order the medical examination of the child, and ultimately could terminate the placement and remove the child where in the best interests of the child. Correspondingly, they "exercised powers of approval, inspection, supervision and removal without any parallel in ordinary family life." 22 Even this "vestigial" level of control was sufficient to ground a finding of vicarious liability. ${ }^{23}$

\section{Vicarious Liability Rejected: Lord Hughes}

For Lord Hughes, the local authority's "business" did not include the provision of family life. Rather, their "business" was to ensure that the children were housed and placed with appropriate carers, and to monitor the suitability of that placement for its duration. Once such

\footnotetext{
${ }^{18}$ Armes, para [59].

${ }^{19}$ Armes, para [59].

${ }^{20}$ Armes, para [60].

${ }^{21}$ Armes, para [62].

${ }^{22}$ Armes, para [62].

${ }^{23}$ See Cox, para [21].
} 
placement was made, the provision of care, love, and affection was all the "business" of the foster parents independently. ${ }^{24}$ The foster parents, not the local authority, actually raised the children as part of their family, and "family life is not consistent with the kind of organisation which the enterprise test of vicarious liability contemplates." 25

This was emphasised by the fact that it was a possibility, and indeed a priority, that the child be housed with a "connected carer". A relative or family friend bringing up a child as one of their own could not be said to be "part of the local authority's "enterprise" and, as his Lordship thought it impossible to distinguish the role of such carers from non-connected foster parents, ${ }^{26}$ the continuing relationship between the foster parents and the local authority was not one which could attract the application of vicarious liability. Lord Reed sought to address this argument by stating that parents who had care of their children would be "raising their own child" which was clearly more independent from the local authority's child care services than raising an unrelated child. ${ }^{27}$ But it is not clear if the same argument holds true for other "connected carers", who are not "raising their own child" but "raising the child as if one of their own" which, saving the degree of familiarity and affinity, would be in the same fashion as a foster carer would raise the child.

\section{E. APPLICATION IN SCOTLAND?}

\section{Background}

Fostering in Scotland is regulated principally by The Looked After Children (Scotland) Regulations 2009. ${ }^{28}$ Foster care is not a homogenous concept, with the varying regimes having different degrees of responsibility and integration on the part of the carers. ${ }^{29}$ Certain fostering arrangements may involve a formal employment relationship, ${ }^{30}$ thereby satisfying the first stage of the vicarious liability enquiry with ease. Outside of this situation, the

\footnotetext{
${ }^{24}$ Armes, para [88].

${ }^{25}$ Armes, para [88].

${ }^{26}$ Armes, para [87].

${ }^{27}$ Armes, para [71].

${ }^{28}$ SSI 2009/210: the "2009 Regulations".

${ }^{29}$ For the pre-Armes English position, see P Morgan, 'Ripe for Reconsideration: Foster Carers, Context, and Vicarious Liability', (2012) 20(2) Torts Law Journal 110.

${ }^{30}$ See for example Johnstone v Glasgow City Council, Cases 41039722016 \& 41039732016

PH, Employment Tribunal, Glasgow, 1 August 2017.
} 
imposition of vicarious liability for delicts committed by foster parents ${ }^{31}$ in Scots law will depend on a close examination on the prevailing legislation. ${ }^{32}$

Scottish local authorities have a duty to accommodate children in need of care, ${ }^{33}$ and may discharge this duty by placement with any "suitable" person. ${ }^{34}$ This regime maintains a distinction between parental carers (those providing care "at home" for children who are the subject of a Compulsory Supervision Order made by a Children's Hearing Panel) ${ }^{35}$, “kinship carers", and "foster carers". Before placing the child with a foster carer, the possibility of placement with the first two classes of carers must be considered. ${ }^{36}$ A snapshot analysis of the potential application of vicarious liability to these categories, which proceeds on the assumption that Armes applies in Scotland, ${ }^{37}$ now follows.

\section{Parental and Kinship Carers}

The obligations placed on parental carers are not extensive: they need not be approved prior to the placement and have only the obligation to notify serious occurrences befalling the child. ${ }^{38}$ They also are subject to a less frequent review period than the other classes of carer: (once a year, as opposed to every six months), ${ }^{39}$ apparently cannot claim for a specific caretriggered allowance, ${ }^{40}$ and are exempt from the local authority's duty to ensure regular visitation by a social worker. ${ }^{41}$ Therefore, it seems likely that, following the comments of Lord Reed, ${ }^{42}$ a court would conclude that a parental carer would not be sufficiently integrated

\footnotetext{
${ }^{31}$ There also is a growing incidence of registered fostering carer agencies. Such agencies independently assess potential carers, provide in-house training and support networks, and pay carers a fee in addition to allowances. This demonstrates a substantial degree of independence from the supervisory local authorities, and therefore, applying the Christian Brothers criteria, these agencies may be vicariously liable for delicts committed by carers operating under their aegis.

${ }^{32}$ For a detailed treatment of children in care, see K Norrie, The Law of Parent and Child in Scotland, 3rd edn (SULI, 2013), especially ch 15.

${ }^{33}$ Children (Scotland) Act 1995, section 25.

${ }^{34}$ Ibid, section 26(1)(a)(iii).

${ }^{35}$ See Children's Hearings (Scotland) Act 2011, section 83.

${ }^{36} 2009$ Regulations, regulation 27(2)(e).

${ }^{37}$ Armes was applied by Sheriff Reid in Grubb $v$ Shannon [2018] SC GLA 13 to find the operator of a beauty salon vicariously liable for the negligence of a beauty therapist using the salon's branding and premises.

382009 Regulations, regulations 8 and 9.

392009 Regulations, regulation 44, cf regulation 45.

402009 Regulations, regulation 33, provides only for foster and kinship care allowances.

${ }^{41} 2009$ Regulations, regulation 46(1).

${ }^{42}$ Armes, para [71].
} 
within the local authority's care-provision business for vicarious liability to arise. Kinship carers essentially have the same obligations as a foster carer (as detailed below) but are appointed and approved on an ad-hoc basis ${ }^{43}$ and are not subject to ongoing review as to their personal suitability for care, which may distinguish them from the position of foster carers.

\section{Foster Carers}

Local authorities must establish a fostering panel ${ }^{44}$ which determines the suitability of prospective foster carers and the appropriate placements for individual carers. ${ }^{45}$ Once the carer is approved, ${ }^{46}$ they must enter into a foster carer agreement with the local authority. ${ }^{47}$ This must detail general matters (for example, the training, review, complaint-handing and placement procedures), financial entitlements, ${ }^{48}$ and the carer's obligations (e.g. notification of incidents and changes in circumstances, confidentiality, not to administer corporal punishment). ${ }^{49}$ Importantly, carers are to care for placed children as if they were part of their family, with "regard to the local authority's immediate and longer-term arrangements for the child." 50 These arrangements will be assessed as soon as the child enters the care system ${ }^{51}$ and be detailed in the "child's plan". 52

In addition to this general agreement, individual agreements must be entered into before each and every placement. ${ }^{53}$ This must detail, among other matters, the child's plan, the objectives which the local authority aims for the placement to achieve, the financial support which the local authority is to provide, the arrangements for local authority visitations, contact with relatives, and the circumstances in which approval must be sought before the child resides outside the foster home or is taken care of by another person. ${ }^{54}$ The foster carer's general suitability to serve as a care provider is kept under frequent review. ${ }^{55}$

\footnotetext{
432009 Regulations, regulation 10.

442009 Regulations, regulation 17.

452009 Regulations, regulation 20.

462009 Regulations, regulation 21.

472009 Regulations, regulation 24.

482009 Regulations, regulation 33.

492009 Regulations, Schedule 6.

502009 Regulations, Schedule 6, para 6(c).

512009 Regulations, regulation 4.

522009 Regulations, regulation 5, and Schedule 2, Part II.

532009 Regulations, regulation 27(2)(g).

542009 Regulations, Schedule 4.

552009 Regulations, regulation 25.
} 
Furthermore, each individual placement is reviewed specifically, ${ }^{56}$ with regular visits to be made by social workers. ${ }^{57}$ If the local authority concludes that the placement is no longer in the best interests of the child, it should terminate the placement forthwith. ${ }^{58}$

It is submitted that the level of integration and control present in these arrangements goes beyond that detailed in Armes. The "child's plan" identifies the needs of the child and is formulated by the local authority in consultation with an array of parties, and the foster carer is tasked with caring for the child in accordance with the plan. In that sense, the foster carer is "integrated" within the individual care regime provided for the child by the local authority, and the carer's success in meeting those needs is kept under sustained review. ${ }^{59}$ The existence of specific agreements detailing a particular carer's responsibilities, and another agreement detailing their responsibilities in the context of a specific placement, is indicative of a reasonably high level of control on the part of the local authority, and strengthens the analogy with employment. The fostering panels also must review the approval of foster carers, independently from their duty to review individual placements, which suggests that the carers are not independent care-providers for individual placements, but an integrated part of the local authority's care-provision service, as the review must occur regardless of whether or not any children presently are placed with the carer.

\section{F. CONCLUSION}

Armes is a significant decision. It entails that acts of abuse in ordinary domestic or social environments may, depending on the degree of integration of the perpetrator into its "business", render a defendant vicariously liable. While one cannot doubt that the result is a "fair, just, and reasonable" one, the analysis seems to be complicated by reliance on the full suite of the Christian Brothers factors. Nevertheless, using Armes's touchstones of integration and control, this note suggests that the imposition of vicarious liability in Scotland is a likely consequence of the local authority's decision to place a child with a foster carer, but may not follow if the placement is with a kinship or parental carer.

Bobby Lindsay

University of Glasgow

\footnotetext{
562009 Regulations, regulation 45.

572009 Regulations, regulation 46.

582009 Regulations, regulation 47.

${ }^{59} 2009$ Regulations, regulation 45(5)(b).
} 